Article

\title{
Critical Issues Affecting Groundwater Quality Governance and Management in the United States
}

\author{
Jacob D. Petersen-Perlman ${ }^{1}$, Sharon B. Megdal ${ }^{1, *}$, Andrea K. Gerlak ${ }^{2}$, Mike Wireman ${ }^{3}$, \\ Adriana A. Zuniga-Teran ${ }^{2}$ and Robert G. Varady 2 (D) \\ 1 Water Resources Research Center, University of Arizona, 350 North Campbell Avenue, Tucson, \\ AZ 85719, USA; jacobpp@email.arizona.edu \\ 2 Udall Center for Studies in Public Policy, University of Arizona, 803 East First Street, Tucson, \\ AZ 85719, USA; agerlak@email.arizona.edu (A.K.G.); aazuniga@email.arizona.edu (A.A.Z.-T.); \\ rvarady@email.arizona.edu (R.G.V.) \\ 3 Graniteridge Groundwater, 274 Granite Drive, Boulder, CO 80302, USA; graniteridgegw@q.com \\ * Correspondence: smegdal@email.arizona.edu; Tel.: +1-520-621-9591
}

Received: 21 March 2018; Accepted: 29 May 2018; Published: 5 June 2018

\begin{abstract}
Groundwater is increasingly important for meeting water demand across the United States (U.S.). Forward thinking governance and effective management are necessary for its sustainable use. In the U.S., state governments are primarily responsible for groundwater governance (i.e., making laws, policies, and regulations) and management (i.e., implementation of laws, policies, and regulations). This decentralized system results in diverse strategies and practices. We surveyed a water quality professional from each state to better understand commonalities and differences across states. These professionals identify a wide assortment of groundwater issues and concerns, including quality and quantity impairment, staffing and budget issues, private well vulnerability, and overdraft. Respondents indicate contamination problems from natural and anthropogenic sources. Most respondents report that their states have significantly changed groundwater quality policy during the past 30 years. While most states have multiple funding sources for water quality programs, program budgets have decreased in the last decade, thereby hindering effective implementation of new policies. Over half of respondents indicate that water-quality/water-level monitoring and increased groundwater pumping will require more attention over the next decade. Several respondents anticipate groundwater regulation changes in the next five years. We discuss how our findings align with current groundwater uses in the U.S.
\end{abstract}

Keywords: groundwater governance; groundwater management; water policy; United States

\section{Introduction}

Groundwater quality issues have been rising to great prominence within the United States (U.S.), as the contamination of groundwater is becoming a widespread problem [1]. These problems include reports of groundwater contamination by coal ash [2], industrial storage tanks [3], seawater intrusion [4], arsenic [5], and agriculture [6]. In a previous survey of state water officials, groundwater quality was cited as a number-one challenge for groundwater management in U.S. states [7].

Groundwater is an essential resource in the U.S. Approximately $20 \%$ of total freshwater withdrawals within the U.S. come from groundwater sources, totaling more than $105 \mathrm{MCM}$ of water per year [8]. Though overall groundwater use was estimated by states to decrease from the year 2000 to the year 2010, largely due to reductions in agricultural usage [8], current practices in many regions of the country allow for use of groundwater that exceed recharge rates, leading to sustained and long-term depletion [9]. Further, the number of people dependent on groundwater for drinking 
water is increasing. Approximately 130 million U.S. residents rely on groundwater as a partial or exclusive source of drinking water supply [10], though the dependency on groundwater varies based on geographic location. Approximately $87 \%$ of 150,000 public water systems in the U.S. rely on groundwater resources [9]. An almost uniform increase in the pumping rates [11] is a symptom of increasing dependence on groundwater as a drinking water supply [12].

Experts agree that study of groundwater governance institutions and policies is needed to identify models for good groundwater governance [13]. In recent years, groundwater governance has received growing attention in scholarly work [13-20]. Notable efforts involving government officials, academics, and other expert practitioners include the Global Environmental Facility-funded project "Groundwater Governance: A Global Framework for Action" [21], and the Organisation for Economic Co-operation and Development's Water Governance Initiative, which focuses on governance on all types of water [22]. Varady et al. [18] reviewed 10 case studies of groundwater governance representing diverse global regions and local contexts. Though there is an international-level interest in groundwater practices and there are some transboundary aquifers, groundwater is inherently a local resource for most extraction and management practices.

In the U.S., research related to groundwater governance and management in the 50 U.S. states is limited. Other analyses have focused on the watershed scale e.g., [23-27], the regional scale [19,28,29], or internationally-shared watersheds e.g., [18,20,30-32]. Though some research has been conducted on state-level groundwater governance and management in the U.S. [33-36], few researchers have examined water governance and management at the state level, despite the fact that most governance strategies and management actions are focused at this level.

Studies of priorities and approaches related to addressing groundwater quality remain limited, even though water quality is recognized as a problem worldwide. The United Nations Millennium Development Goals include Target 7c, which called for halving the number of people without sustainable access to safe drinking water between 1990 and 2015 [37]. Problems involving groundwater quality are not limited to the developing world. To better understand and identify commonalities and differences in groundwater governance strategies and practices concerning water quality, we conducted a national survey of water quality professionals in U.S. states. We begin with an exploration of the nature of groundwater as a common-pool resource and its difficulties in governance and management, particularly relating to water quality. We then introduce our survey methods and findings. We discuss how these findings reflect current uses of groundwater in the U.S. We conclude by discussing future research directions designed with the aims of identifying best practices in groundwater management and governance.

\section{Groundwater Governance and Water Quality}

This section discusses how the nature of groundwater makes it difficult to govern and manage, along with principles for effective groundwater governance and management. Though there are several examples that are drawn from the U.S., many observations made in this section are universal.

\subsection{The Nature of Groundwater and Difficulties of Governance}

The literature related to common-pool resources suggest that common access may lead to over-exploiting these resources without effective institutions. People do not restrain their use of a common-pool resource without the presence of an external enforcer [38]. If effective rules and institutions are present that limit access and define user rights, overuse and other negative effects can be prevented [39-42].

Groundwater can be classified as a common-pool resource due to: its subtractability, meaning that each user is able to subtract from the welfare of other users; and low excludability, meaning control of access [43]. Groundwater may be particularly susceptible to the problems associated with the commons, as aquifers are relatively inexpensive and reliable to develop, once technology and energy are accessible to potential users [44]. 
Problems associated with groundwater quality are particularly difficult to mitigate due to the common-pool nature of groundwater. Once contamination occurs in groundwater, it is difficult to characterize [19] and to remediate [16,45]. Theesfeld [14] identified a set of characteristics that make groundwater difficult to manage. We provide some insights on these characteristics as follows:

- Irreversibility. The pumping of groundwater may lead to irreversible physical damage to the aquifer or the ground above through processes such as land subsidence [46]. In addition, the damage caused by contamination may be expensive, difficult, or even impossible to remediate, even with methods, such as pump and treats and surfactant-enhanced aquifer remediation [47].

- Time lag. The effects of withdrawal or contamination may take time to manifest. Time lags between withdrawal and subsequent impacts are challenging for water management [48]. Groundwater flow and transport processes are slow. Contamination is often detected well after sources have become active or may have even ceased to exist [49].

- Indivisibility. An aquifer cannot be fenced off or physically protected. It should be noted, however, that an aquifer's vulnerability is dependent on type of contamination, degree of pollution, and its hydrogeology [50].

- Fuzzy boundaries. Due to the great variability in hydrogeologic settings, defining the exact boundaries of an aquifer is quite challenging. There is no broadly accepted agreement that defines aquifer boundaries in the international community [51].

- Hydrogeological uncertainty. The great variation in hydrogeology and the diversity of groundwater uses make governance and management very difficult. This is evident in places such as California, where uncertainties of aquifer boundaries and overlaps in Groundwater Sustainability Agency borders compound difficulties in groundwater governance [36]. The complexities of groundwater-surface water interactions complicate water management due to inadequate coordination among state agencies. Uncertainty in hydrogeology also makes it difficult to know how much water is within each territory of transboundary aquifers. Data needs. Like surface water data, groundwater data are often of uncertain quality. Groundwater data are often much less available compared to surface water data. Sugg et al. [35] suggest that more technical support and groundwater data are needed for groundwater conservation districts in Texas to be effective.

- Structure of abstraction. How many wells are extracting groundwater and how much these wells are abstracting groundwater are not always properly monitored. Arizona was mandated to control groundwater depletion in order for the Central Arizona Project to be constructed [35].

- Information asymmetry. Information regarding groundwater is usually limited and asymmetrically held, creating difficulties for management. This can occur when water users have better knowledge of their historic water use practices than regulatory officials [52].

In addition to the above, scale can also create difficulties in managing and governing groundwater. Certain aquifers, such as the Ogallala Aquifer in the central U.S., may underlie thousands of square kilometers. However, management and impacts of groundwater use are specific to their context (and sometimes their location), given the variation in geology and water use characteristics in different parts of the aquifer [9].

\subsection{Effective Groundwater Governance and Management}

Many problems associated with groundwater, including those with quality, may be due to poor governance [13]. Groundwater governance can be defined as the "overarching framework of groundwater use laws, regulations, and customs, including the processes of engaging the public sector, the private sector, and civil society" (Reference [7], p. 678). While governance refers to laws, policies, and regulations, management refers to the actions to implement these laws, policies, and regulations [7].

Most of the impediments to sustainable groundwater management observed across the world can be linked to failures in groundwater governance structures $[17,20,21]$. Many of these impediments 
are due to challenges related to: fragmented and overlapping jurisdictions and responsibilities, competing priorities, water rights and water pricing structures, and diverging opinions on how it should be governed and managed [53]. Additionally, the lack of sufficient knowledge and physical data concerning aquifer characteristics and behaviors, including discharge, recharge, base flow, and aquifer-dependent ecosystems, as well as linkages between human well-being and groundwater ecosystem services, render water resource planning and management more challenging and difficult to predict [15].

Another problem with governing groundwater sustainably is that groundwater policy horizons are often inconsistent with natural groundwater time scales. Groundwater policy horizons are typically from 5 to 20 years [54], while mean residence time of groundwater can vary from less than 6 years to over 1,000,000 years [55]. This demonstrates how groundwater policies addressing quality and quantity issues may not be in place long enough to effectively manage them. The use of and the dependence on groundwater also varies with time-often, when droughts occur, large water users turn to groundwater to make up for deficits in surface water supplies. In California, groundwater supplies $60 \%$ of water used during a drought, as opposed to a normal year, when groundwater supplies $40 \%$ of supplies [9].

Effective governance of shared common-pool resources, such as groundwater, may be possible under certain conditions, including subtractability and excludability [40]. Effective groundwater governance is also easier when the user population, the uses, and economic and social conditions are relatively stable or change only moderately, and when communities that use the resource frequently interact [40].

\subsection{Groundwater Quality Governance and Management in the United States}

Good governance of groundwater needs to consider both quantity and quality, but most legal frameworks treat them separately [15]. Within the U.S., water management has been decentralized historically [56-58], more than the similarly federalized government of Australia and even more than the European Union [59]. The federal government sets water quality goals, particularly through measures such as the Clean Water Act that requires states to set standards to protect water quality so that all waters of the U.S. attain "fishable" and "swimmable" status [60]. However, it has delegated to state implementation of those standards rules, and practices for water use [56-58]. States also have discretion to interpret the standards for different waterways [60].

Water management in the U.S. has also become increasingly complex and fragmented. At the federal level alone, more than 25 federal agencies have water as part of their mission statement [61]. These agencies implement over 100 federal water programs for water quality and quantity, navigation, recreation, climate change, hydropower, natural hazards management, and integrated water resources management [62]. In addition, more than 100,000 local water-related organizations and more than 300 agencies departments in 50 states have responsibilities related to water [63].

Combined with the decentralized nature of water management in the U.S., the fact that groundwater is a common-pool resource that is difficult to manage, the separation of quality and quantity in legal frameworks, and the wide variety of agencies involved, makes it very difficult to understand the state of groundwater quality governance in this country. The purpose of this paper is to integrate groundwater quality issues and challenges in the U.S. states to increase our understanding of groundwater governance.

\section{Methods}

Our survey questionnaire (see the Supplementary File) was developed to achieve a better understanding of the current status of groundwater use, laws, regulations and management in the 50 U.S. states related to water quality. We aligned our approach with some of the recommendations for comparative water analyses recommended by Blomquist et al. [64], including being mindful of the intergovernmental relation context and being attuned to water policy reforms. 
We designed our survey to investigate institutions at the same level of governance (state) and to inquire about intergovernmental relations related to groundwater quality, such as relations between agencies and relations between states. Although we inquired about potential water policy reforms, we did not select cases based on the adoption of water policy reforms. Seeking deeper insights into the groundwater quality strategies and practices of all 50 states that were recently attempted or are being attempted was beyond the scope of the survey. The survey focused on six substantive elements: (1) groundwater concerns and use; (2) groundwater quality management and monitoring; (3) scopes of groundwater quality regulatory programs; (4) groundwater quality-quantity connections; (5) the scope of resources available and needed, and research and collaboration between local, state, and federal agencies; and (6) exploring future trends in groundwater management. The questions either were multiple choice, binary (yes/no questions), open-ended, or provided a Likert scale (4-7 points). The survey was administered through Qualtrics software. This study was approved by the Institutional Review Board (IRB) of our academic institution. The survey was deemed exempt from a comprehensive IRB review due to the lack of risk to the respondents, among other criteria.

Our survey built on work by Gerlak et al. [65], which surveyed state agency officials about the extent and scope of groundwater use, governance strategies (laws and regulations) and management tools. Similarly, we identified participants working in state water agencies to complete the survey. Participants were identified through online searches of agencies with authority for water quality in each state. In states where the agency failed or declined to respond, state-level employees at the federally authorized state Water Resource Research Institutes or an official at the state-level U.S. Geological Survey (USGS) Water Science Center were asked to complete the survey. The availability of resources for conducting the study limited the survey to one respondent from each state, much like the first survey on groundwater governance. The limitations of this approach should be noted. Surveying one respondent from each state and prioritizing responses from agencies in charge of water quality obviously weight water quality issues with greater importance. Additionally, relying on one respondent per state will give incomplete responses regarding state priorities, as opinions are bound to differ across various state agencies. In addition, we gathered data from the USGS on groundwater use across the U.S. to complement our survey results. We compared our survey responses with USGS groundwater use data. We also categorized certain survey responses based on similar responses. We used descriptive statistics for reporting the results.

\section{Findings}

In reporting on our findings, we show the number of state respondents as N. Twenty-two state respondents cited preventing and/or mitigating impairment of water quality as the number-one concern in their states (Figure 1). Forty-five respondents selected groundwater quality as one of the top-three water management concerns for their state.

Our findings also suggest that while the total amount of groundwater used has decreased slightly in the U.S., groundwater quantity remains a top concern (see Figure 2 and below for further discussions) despite an estimated decrease of $6 \%$ in groundwater use from the year 2000 to the year $2010[8,66]$. Figure 2 shows how many respondents listed each concern as a top-three state groundwater concern. Respondents also reported multiple sources of groundwater contamination. We also found that the jurisdictional complexity in water management, which is common across the nation, is also common in groundwater governance. Our results indicate that financial constraints are a significant concern to many U.S. state agencies (Figure 2; "budget" and "staffing issues" are selected as areas of concern by 29 and 27 states, respectively). Finally, we found that monitoring and regulation are conducted by multiple organizations at the federal and state levels, and that regulations are changing to adapt to emerging issues related to land use changes and economic activities. However, many issues, particularly those of budget, staffing, and changes in regulations, will require more continuing attention in the years to come. 


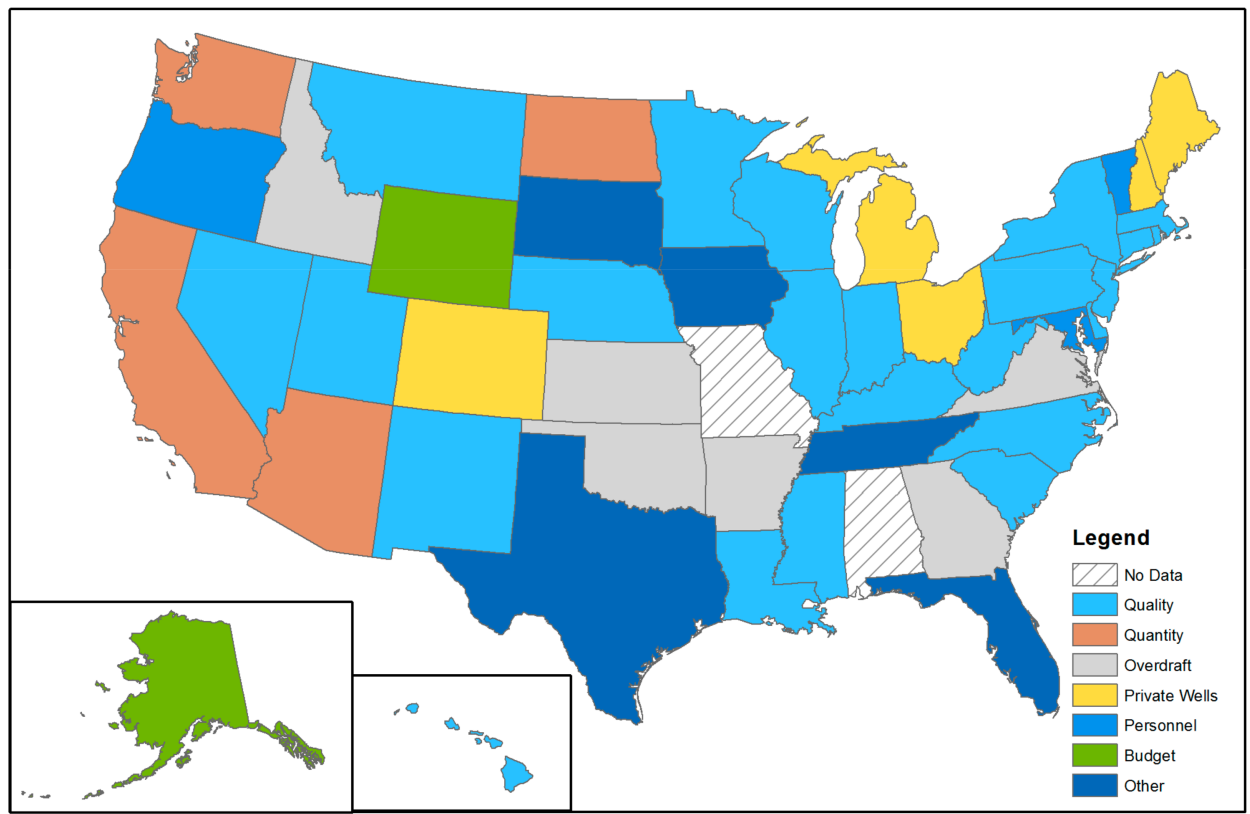

Figure 1. Number one ranked groundwater concerns, by state $(\mathrm{N}=48)$.

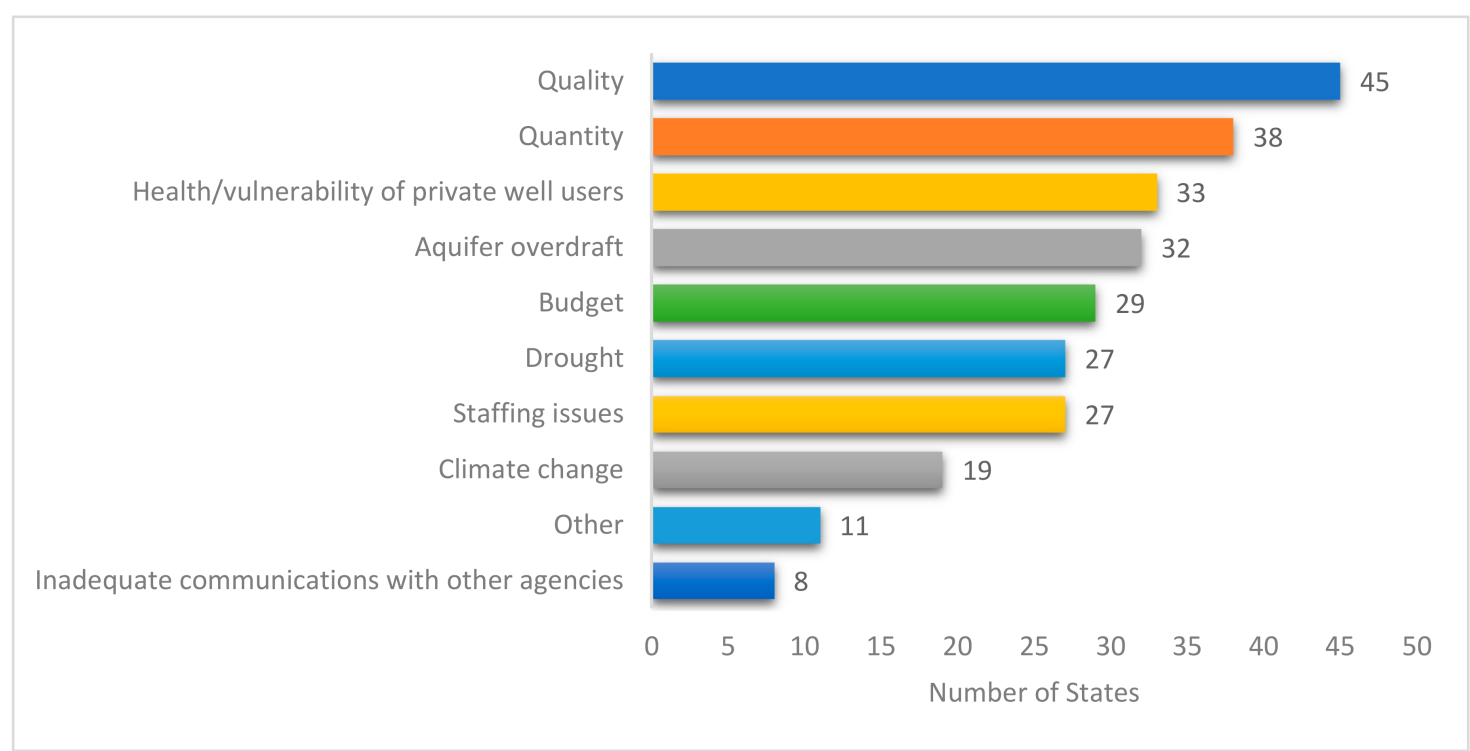

Figure 2. The most selected groundwater concerns identified by state water officials $(\mathrm{N}=48)$.

\subsection{Sources of Groundwater Contamination}

State water professionals reported multiple sources of water quality contamination, including agricultural activities, naturally occurring contaminants, industrial activities, and underground storage tanks (Figure 3). The respondent from Tennessee selected 15 of the 17 contaminant sources on the survey list, while respondents from Indiana, Kentucky, Michigan, Minnesota, Missouri, New Mexico, and West Virginia each selected 10 or more of the listed contaminant sources. In contrast, the respondents from Arkansas, Iowa, Vermont, and Wisconsin each selected only two of the listed contaminants. 


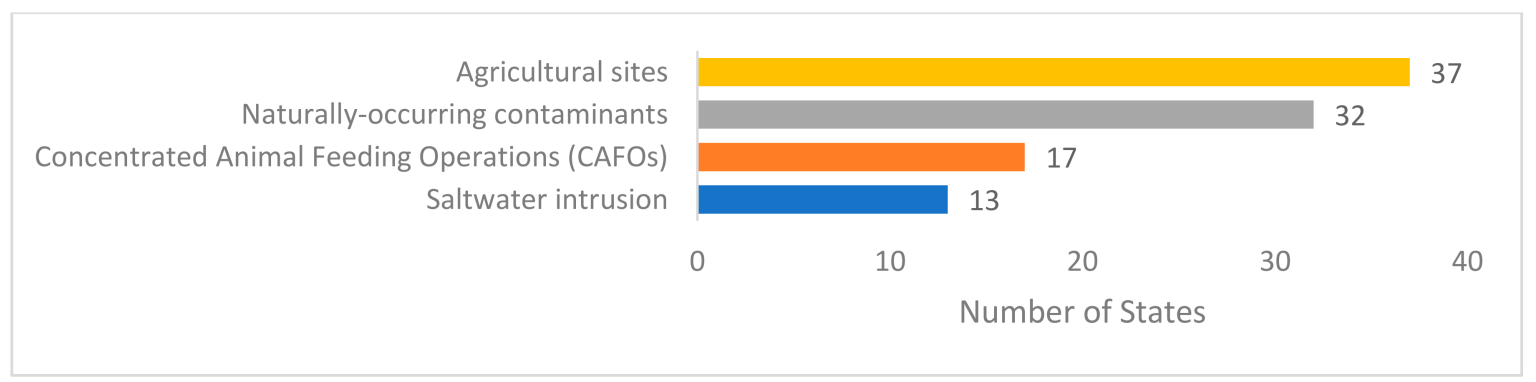

(a)

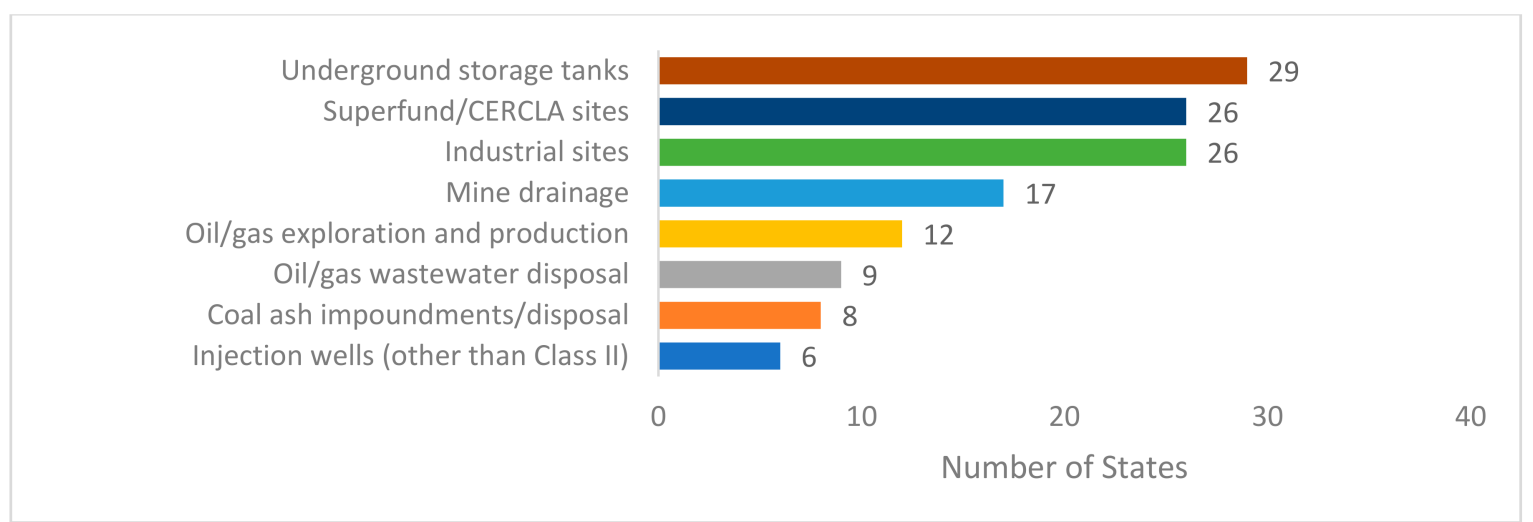

(b)

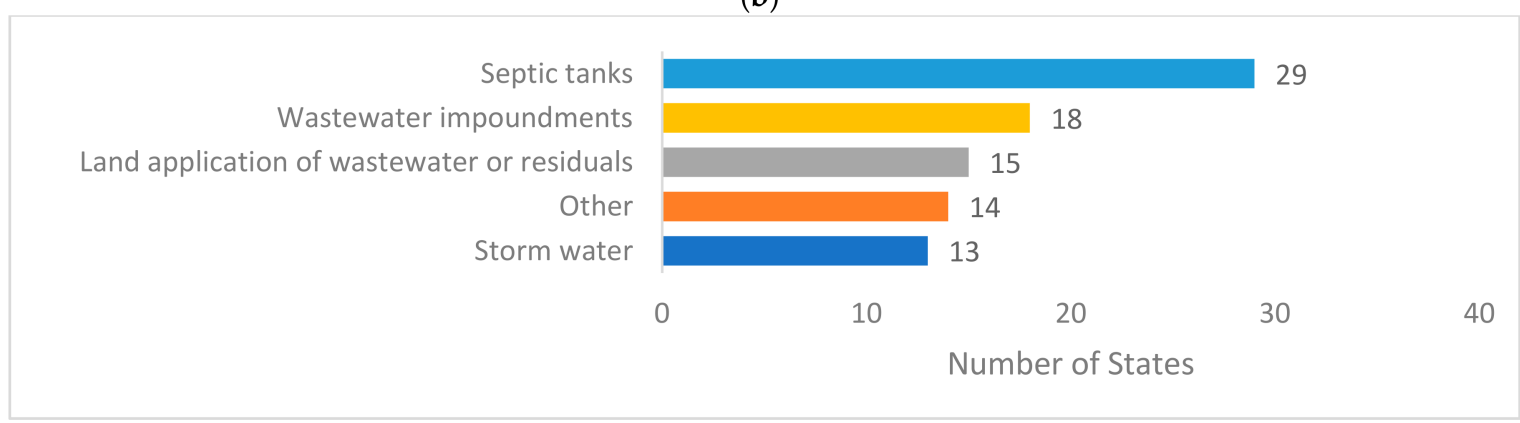

(c)

Figure 3. Contamination sources: (a) agricultural and natural; (b) industrial; and (c) municipal and other $(\mathrm{N}=49)$.

Respondents were asked to rank the top three contaminants of concern that their states are managing. Their number-one responses are shown in Table 1. Agricultural sites are the most selected contaminant source, followed by naturally occurring contaminants. More than half of respondents surveyed also identified underground storage tanks, Superfund/Comprehensive Environmental Response, Compensation, and Liability Act (CERCLA) sites, industrial sites, and septic tanks as major sources of contamination.

Table 1. Number one ranked groundwater contaminant sources by sector in each state $(\mathrm{N}=47)$.

\begin{tabular}{cc}
\hline Groundwater Contaminant Source by Sector & Number of States \\
\hline Agricultural & 16 \\
Industrial/Mining & 9 \\
Naturally Occurring Contaminants & 7 \\
Wastewater Related & 5 \\
Other & 10 \\
\hline
\end{tabular}


From these sources of contamination listed in Figure 3 and Table 1, state water professionals reported a variety of specific contaminants that their state works to mitigate. Most (81\%) respondents identified "nitrate/nutrients" as a contaminant of concern within their states, making it the most selected contaminant of concern, followed by chlorinated solvents and metals (Figure 4).

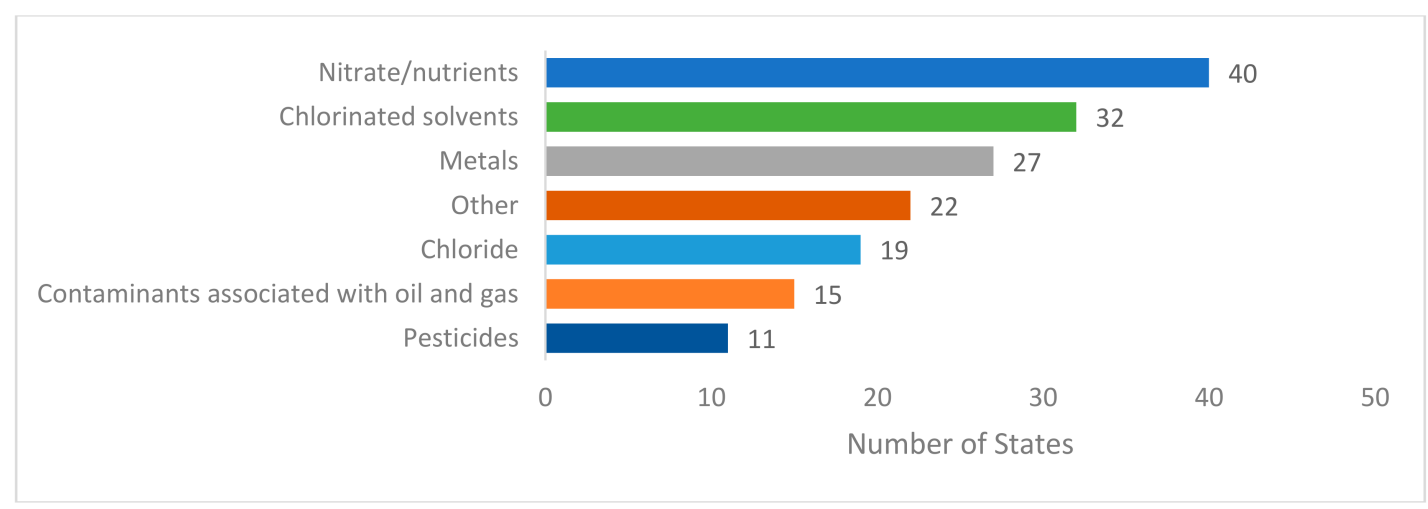

Figure 4. Most selected contaminants of concern $(\mathrm{N}=49)$.

\subsection{Contamination Source and Water Use}

Examining data from the 2000 and 2010 USGS water-use circulars, we observed a shift in groundwater use by sector across the states, where some states decreased their use for agriculture and increased their use in industry or mining. Overall, agriculture had an estimated decrease in groundwater use of around 13\%, while industry and mining had an estimated increase of around $18 \%$, and public and domestic use had an estimated decrease of 1.5\% (Figure 5).

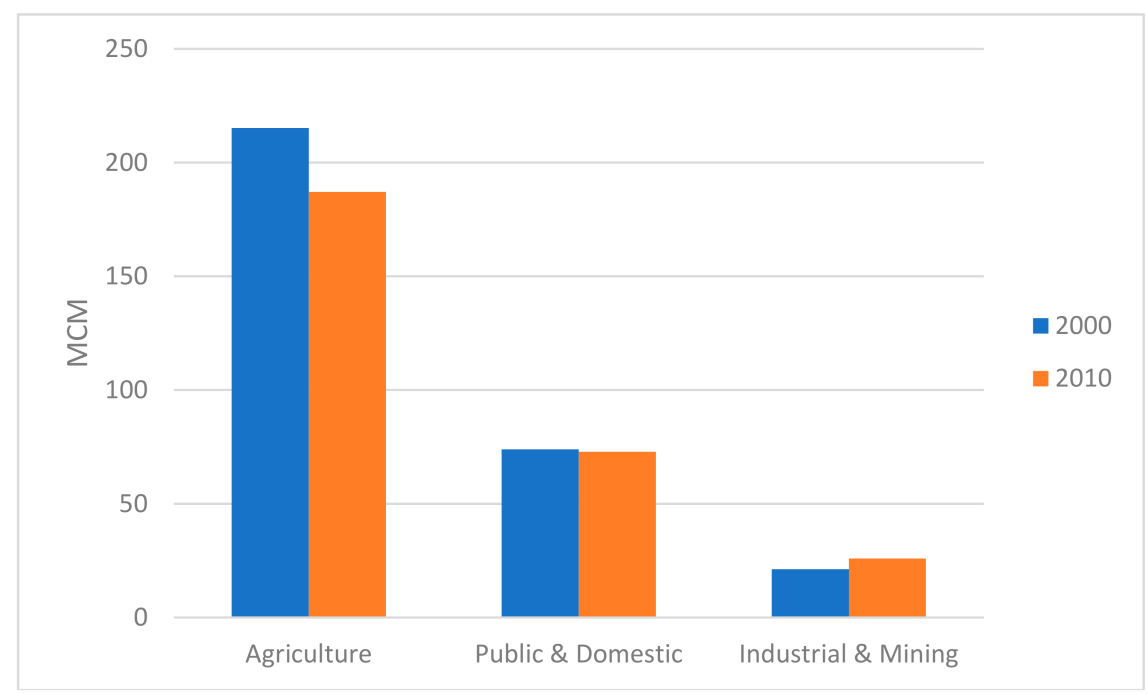

Figure 5. Groundwater use in 2000 and 2010 by sector (data from USGS circular reports). This graph does not consider livestock, aquaculture and thermoelectric power uses, because these are lower than $1100 \mathrm{mgd}$ and this smaller scale is not clear in the graph.

Of the 16 states that rank "agriculture" as the top groundwater contaminant source, 10 of them reported irrigation as the highest use in either or both the 2000 or 2010 USGS water use circulars. Only one of the nine states that list "industrial/mining" as the top groundwater contaminant source reported that either the industrial or mining sector as the highest use. Four of the seven states that list "naturally occurring contaminants" as the top source of contamination estimated that public supply was the highest water use. 


\subsection{Overlapping Jurisdictions}

Just as aquifer boundaries do not often align with state boundaries, groundwater quality governance and management frequently occur at multiple scales. For example, while federal regulations mandate drinking water quality standards (e.g., Safe Drinking Water Act), groundwater is managed at the state or sub-state level. In many cases, federal agencies such as the USGS or the U.S. Environmental Protection Agency (EPA) conduct groundwater quality monitoring, yet the responsibility to comply with regulations lies at the state level. Most state respondents (92\%) indicated that they rely on local agencies to implement regulations on groundwater quality, and $60 \%$ rarely rely on federal agencies. There are also issues of jurisdiction at the state agency level; $57 \%$ of state respondents reported that state quantity and quality agencies have separate jurisdictions.

Not all states administer groundwater in the same way, yet certain regulations apply to all states. Trans-jurisdictional aquifers (aquifers that extend across several state boundaries) further aggravate this complex jurisdictional situation. Some states using groundwater for economic activities (e.g., agriculture, mining, and oil/gas development) may be responsible for groundwater contamination in neighboring states. Likewise, land use changes in a state (e.g., urbanization) may affect surface water systems (increased runoff and sedimentation) and groundwater quantity and quality in basins that permeate to other states. Remediation actions, therefore, become problematic and difficult to implement in a holistic approach.

Nevertheless, there are regulations in place that deal with this jurisdictional complexity. Fifteen respondents indicated that they have regulations for interstate conflicts in place. Ten respondents indicated that their states have regulations related to litigation, while 28 responded that their states have regulations related to water rights. In addition, tribal water right settlements exist in eight states, and three states have regulations related to international conflicts. State respondents from Idaho, Montana, New Mexico, Oklahoma, South Dakota, Texas, and Washington indicated that the issue of water rights is the number one future concern for their state.

\subsection{Financial Constraints}

Many states face significant financial constraints for groundwater governance. Our survey indicates that "budget" is the fifth-most selected groundwater concern as identified by state water officials. More than half of the respondents $(\mathrm{N}=29)$ selected financial capacity as a concern for groundwater governance in their state. Furthermore, 13 state respondents selected budget as one of the top three groundwater concerns, and 8 respondents selected personnel. Alaska and Wyoming selected budget constrains as their number one groundwater concern, while Maryland, Oregon and Vermont selected personnel as their number-one concern.

States obtain their funding from several sources, but respondents reported that state budgets are not enough and seem to be decreasing. Our results show that most states receive the funding for water quality programs from the federal government $(\mathrm{N}=40)$, followed by the state general fund $(\mathrm{N}=34)$. Other sources of funding include economic instruments such as taxes and fees (permit, user, and mitigation). Despite the diversity of funding sources, approximately $59 \%$ of our respondents indicate that their budget is less than it was a decade ago, while approximately $20 \%$ said their budget had increased during that time period. Approximately $12 \%$ of respondents said that their budget had stayed about the same $(\mathrm{N}=45)$.

Staff numbers working on groundwater-related programs vary widely across the states. Louisiana is the state that reported the fewest employees (20), while Texas employs the largest number of people (3000). The average number of full-time staff across the state agencies surveyed is 792, but the average number of full-time staff working on groundwater-related programs is only 46. 


\subsection{Monitoring and Regulation}

Monitoring groundwater quantity and quality is essential for governance [18]. In the U.S., there are multiple organizations that conduct groundwater quantity and quality monitoring other than the state water agencies, including non-water state agencies, federal agencies, academic institutions and non-governmental organizations (NGOs) (Table 2). Our findings show that the USGS conducts monitoring in $67 \%$ of the states $(\mathrm{N}=34)$, followed by state departments of environmental protection/quality that conducts monitoring in $55 \%$ of the states $(\mathrm{N}=27)$.

Table 2. Organizations that conduct groundwater quality monitoring $(\mathrm{N}=49)$.

\begin{tabular}{cc}
\hline Organization & Number of States \\
\hline USGS & 34 \\
State Dept. of Environmental Protection/Quality & 27 \\
Colleges/universities & 26 \\
State Geologic Survey & 20 \\
Local agencies & 19 \\
Other state agency & 15 \\
State Department of Agriculture & 15 \\
EPA & 11 \\
Conservation/Natural Resource Districts & 9 \\
Other & 6 \\
Dept. of Natural Resources & 5 \\
NGOs & 5 \\
Tribes & 3 \\
\hline
\end{tabular}

It is not surprising to find that so many states monitor groundwater quality because it is indirectly mandated by federal regulations. However, $15 \%$ of the survey respondents indicated that their states do not include groundwater monitoring in their overall water resources monitoring strategy, and 17\% of the respondents stated that their states do not have a water quality monitoring strategy. In addition, over half (29) of state respondents stated that budgets for monitoring and use verification are less than 10 years ago.

In many states, groundwater regulations have adapted to emerging issues. While $44 \%$ of the respondents indicated that they have not seen significant changes in groundwater policy in the last decade, the rest of the states have experienced important changes. For example, changes to Clean Water Act Total Maximum Daily Loads requirements were mentioned by $22 \%$ of the respondents, and $33 \%$ of the respondents indicated that their state has initiated limits on groundwater withdrawals in the last decade. Other significant changes reported in the survey include changes in well construction standards $(\mathrm{N}=10)$, changes in groundwater quality standards $(\mathrm{N}=8)$, new laws related to groundwater quality standards $(\mathrm{N}=7)$, non-degradation $(\mathrm{N}=1)$, and aquifer exemptions $(\mathrm{N}=1)$.

Land use change and growing economic activities that utilize groundwater have also affected groundwater policy in some states. Twenty percent of respondents reported that storm water has become an important groundwater quality issue that drives policy changes as cities have grown. Nine respondents indicated that their state created regulations related to concentrated animal feeding operations. Eight respondents indicated the emergence of new water quality regulations related to oil and gas development. In addition, two respondents indicated that their state now requires the establishment or the declaration of intended uses.

\subsection{Future Trends}

State water professionals were also asked to identify future trends in groundwater management. The respondents indicated that some issues will require increased attention in the next decade, including water quality monitoring, increased groundwater pumping, and water level monitoring (Table 3). 
Table 3. Likely issues requiring attention in the next 10 years $(\mathrm{N}=49)$.

\begin{tabular}{ccc}
\hline Category & Issue & Number of States \\
\hline & Oil and gas exploration and production & 18 \\
Industry-Related & Resource development & 15 \\
& Management of industrial waste & 13 \\
& Mine drainage & 10 \\
\hline Policy/Regulations-Related & Water quality monitoring & 34 \\
& Water level monitoring & 32 \\
& Water rights & 28 \\
& Interstate conflicts & 15 \\
& Stakeholder disagreements & 15 \\
& Primacy program & 12 \\
& requirements/responsibilities & 10 \\
& Litigation & 8 \\
& Tribal water rights settlements & 3 \\
\hline & International conflicts & 34 \\
& Increased groundwater pumping & 27 \\
& Climate change & 11 \\
& Saltwater intrusion & 6 \\
\hline
\end{tabular}

Most respondents (55\%) indicated that changes in groundwater quality regulation are likely to be considered in the next five years $(\mathrm{N}=47)$. State water professionals were also asked about which groundwater regulations and/or policies are likely to be amended or proposed in their states in the next five years (Table 4 ).

Table 4. Likely groundwater regulations/policies in the next five years $(\mathrm{N}=47)$.

\begin{tabular}{cc}
\hline Likely Groundwater Regulations/Policies & Number of States \\
\hline New water quality standards for unregulated contaminants & 20 \\
Regulations of surface activities that affect groundwater & 18 \\
To help assure sustainable use of groundwater & 17 \\
Recharge regulations & 11 \\
None & 11 \\
Groundwater quality standards & 8 \\
Pumping regulations & 8 \\
Injection regulations & 6 \\
Oil and gas exploration and production & 5 \\
Concerning groundwater dependent ecosystems & 4 \\
Other & 3 \\
\hline
\end{tabular}

\section{Discussion}

The results of this survey indicate how states also face a variety of similar complications in groundwater quality and governance, including budgetary limitations and fragmented and overlapping jurisdictions, while groundwater quality is an important concern for almost all U.S. states and many states have similar problems in this regard. In contrast, state respondents identified differences between their states, including a variety of sources of contamination and which organizations conduct groundwater quality and quantity monitoring. The results particularly illustrate a diversity of regulatory policies and management strategies among states.

Groundwater governance is most effective when users support monitoring and managing its use, the monitoring and verification can be done at a low cost, and when the use of the aquifer is highly excludable [40], many states face some obstacles in achieving these characteristics for effective groundwater governance. Adequate monitoring is more difficult when constrained by budgetary and 
staff concerns, both of which were cited as top concerns by many state respondents. Decreases in budgets for monitoring and use verification in the last 10 years make consistent and robust monitoring efforts become more difficult. Over half of respondents selected financial capacity as a concern, with many states reporting that they receive funding from multiple sources. This creates greater difficulty in maintaining relatively stable economic conditions within agencies charged with managing groundwater. Lack of financial, regulatory, and personnel consistency, with agency needs for staff, funding, and changes in regulations, can also make the groundwater quality problems of irreversibility and time lag (as noted in Reference [14]) more difficult to mitigate.

Other problems associated with groundwater governance and management include fragmentation and overlapping jurisdictions, as noted in References [14,54]. Many of the state respondents allude to complex jurisdictional regimes within their states for groundwater. Multiple agencies, including federal, state and local agencies, monitor groundwater quantity and quality within the states. Several state respondents reported that monitoring groundwater is not included within states' overall water resources monitoring strategies. Many state respondents reported that regulation and management of groundwater quantity is administered by a different state agency than groundwater quality, despite that groundwater governance would be improved if quantity and quality were considered in the same legal framework, as was suggested by Knüppe [15]. Despite these complex governing policies and regulations, decreases in groundwater use in several states (based on the USGS survey data) suggests improved management of the resource within those states. An estimated increase in groundwater use for industrial and mining purposes may play a larger role in future groundwater governance and management.

A complicating factor of water governance is that political and watershed boundaries often do not align, leading to inherent conflicts between user groups. Incorporating multiple management and governance frameworks within transboundary aquifers, both with Mexico and Canada, and with neighboring states, makes management and governance of these shared resources more difficult. Despite the wide extent of some aquifers, such as the Ogallala Aquifer in the central U.S., groundwater is essentially a local resource [67], implying that management and pollution protection should be carried out close to groundwater users and possible polluters. Of course, every aquifer has its own unique characteristics, and differences in economics, political resources, culture, and other social characteristics can impede basin-wide management [36]. In contrast, choosing a more manageable scale, such as in many basins in California with the implementation of its Sustainable Groundwater Management Act, may affect funding opportunities, and transparency could impact independence and general efficacy [36]. There is no one-size-fits-all solution for scale, but states should consider the benefits and drawbacks of both local and basin-wide approaches for optimal management and governance.

The survey results capture the complexity between scale and jurisdiction, along with the decentralized nature of groundwater governance in the U.S. With over half of state respondents reporting that quantity and quality agencies have separate jurisdictions, addressing quality concerns that are strongly related to quality would seemingly become more complex. Despite this, interagency coordination is still the norm, aside from four states that reported little coordination between quantity and quality agencies.

Though there are certainly limitations to this decentralized approach of groundwater management and governance, such as governing and managing groundwater bodies shared between states and agencies, advantages also exist. For instance, states can tailor their regulations to local (sub-state or state-level) conditions. It also appears that many states prefer this decentralized nature of water governance. In April 2018, the Western Governors' Association, a non-partisan organization of 22 governors in the Western U.S., produced a policy resolution advocating for state-level primacy in water management, and specifically advocated for the federal policy, the Clean Water Act, not to be applied to groundwater, or for the federal government to develop a groundwater quality strategy [68]. 


\section{Conclusions}

This article reports on an investigation in groundwater quality governance and management at the state level in the United States. The results of the survey show the complications (and sometimes advantages) of governing and managing a common-pool resource such as groundwater caused by the extreme degree of decentralization in state-level groundwater governance and management.

Our analysis reveals that there is a jurisdictional complexity that makes groundwater governance challenging, particularly within states with overlapping jurisdictions between state and sub-state agencies, and between states that share major aquifers. The results further show that states have a wide spectrum of regulatory regimes and management practices related to groundwater quality. The fact that monitoring is conducted by multiple agencies, and that regulation is adapting while state budgets are being constrained, implies that implementation of groundwater governance policies and management strategies is becoming more difficult to accomplish.

In this study, we captured the most pressing concerns for groundwater quality management as identified by state water professionals. Almost all of the surveyed state respondents selected groundwater quality as one of the top-three water management concerns for their state, and over half of state respondents selected quality, quantity, health/vulnerability of private well uses, aquifer overdraft, budget, and staffing issues as top concerns. Over half of state respondents also identified water quality monitoring, water level monitoring, water rights, increased groundwater pumping, and climate change as future issues within their states. Most states also face the complications of overlapping jurisdictions. In addition, we found that the issue of water rights is one that many states regard as problematic in the future.

With these results in mind, we call for an agenda for new research on state groundwater governance and management. This survey represents an early step in uncovering the current nature of groundwater governance and management in the U.S. Future research directions include conducting focused surveys to a larger number of participants per state combined with in-depth interviews that capture the complexity of groundwater quality governance and management practices. In addition, investigating the effectiveness of current governance and management, including identifying what metrics are appropriate for measuring effectiveness, should be considered. Surveying multiple parties representing various sectors in groundwater governance and management could also yield additional insights into best practices.

Supplementary Materials: The following are available online at http:/ / www.mdpi.com/2073-4441/10/6/735/s1, Survey Questionnaire.

Author Contributions: S.B.M., A.K.G. and M.W. conceived, designed and performed the experiments; J.D.P.-P., S.B.M., A.K.G., M.W. and A.A.Z.-T. analyzed the data; J.D.P.-P., S.B.M., A.K.G., M.W., A.A.Z.-T. and R.G.V. wrote the paper.

Funding: This work was funded primarily by the Ground Water Research and Education Foundation (GWREF) through a grant entitled "A Survey of Groundwater Governance and Management: Strategies, Challenges, and Opportunities Connected to Water Quality." Additional support was provided by the Technology Research Initiative Fund administered by the University of Arizona Office for Research, Discovery \& Innovation, funded under Proposition 301, the Arizona Sales Tax for Education Act in 2000. We also acknowledge support from the International Water Security Network, funded by Lloyd's Register Foundation (LRF, London, UK), a charitable foundation in the United Kingdom helping to protect life and property by supporting engineering-related education, public engagement and the application of research; and the Inter-American Institute for Global Change Research (IAI, Montevideo, Uruguay) for Project SGP-CRA005, supported by U.S. National Science Foundation (NSF, Alexandria, VA, USA) Grant No. GEO-1138881; and for Research Project CRN3056, supported by NSF Grant No. GEO-1128040.

Acknowledgments: We thank Mike Wireman and Jon Kenning for valuable input throughout the project. We also thank those who tested the survey and the state water professionals for their responses.

Conflicts of Interest: Mike Wireman is a board member of the GWREF but has no financial interest in the Foundation. 


\section{References}

1. De Chaisemartin, M.; Varady, R.G.; Megdal, S.B.; Conti, K.I.; van der Gun, J.; Merla, A.; Nijsten, G.-J.; Scheibler, F. Addressing the groundwater governance challenge. In Freshwater Governance for the 21st Century; Karar, E., Ed.; Springer International Publishing: Cham, Switzerland, 2017; pp. 205-227.

2. Lutey, T. Cleanup of Toxic Coal Ash That Contaminated Colstrip Groundwater Begins. Billings Gazette, 11 January 2018. Available online: http:/ / billingsgazette.com/news/government-and-politics/cleanupof-toxic-coal-ash-that-contaminated-colstrip-groundwater-begins / article_b04a0671-0e10-5162-bb6708e11bd994f0.html (accessed on 31 January 2018).

3. Baker, S. Contaminated Groundwater Seeping into the Trinity River from This Spot Needs Costly Fix. Fort Worth Star-Telegram, 2018. Available online: http:/ / www.star-telegram.com/news/local/community/ fort-worth/article193037129.html (accessed on 31 January 2018).

4. Johnson, J. Farm Bureau Declares Opposition to Proposed Salinas Valley New wells Moratorium. Monterey Herald, 29 January 2018. Available online: http://www.montereyherald.com/article/NF/ 20180129/NEWS/180129825 (accessed on 1 February 2018).

5. Pakianathan, R. Study Measures Arsenic Contamination in Wells. The Dartmouth, 12 January 2018. Available online: http:/ / www.thedartmouth.com/article/2018/01/study-measures-arsenic-contamination-in-wells (accessed on 1 February 2018).

6. Bergquist, L. DNR Board Approves Measure to Limit Manure Pollution in Eastern Wisconsin to Protect Groundwater. Milwaukee J.-Sentinel, 2018. Available online: https://www.jsonline.com/story/ news / politics / 2018/01/24/natural-resources-board-approves-measure-limit-manure-pollution-easternwisconsin-protect-groundwate/1060117001/ (accessed on 1 February 2018).

7. Megdal, S.B.; Gerlak, A.K.; Varady, R.G.; Huang, L.Y. Groundwater governance in the United States: Common priorities and challenges. Groundwater 2015, 53, 677-684. [CrossRef] [PubMed]

8. Maupin, M.A.; Kenny, J.F.; Hutson, S.S.; Lovelace, J.K.; Barber, N.L.; Lindsey, K.S. Estimated Use of Water in the United States in 2010; U.S. Geological Survey: Reston, VA, USA, 2014. Available online: https:/ / pubs.usgs.gov/circ/1405/pdf/circ1405.pdf (accessed on 9 May 2018).

9. Patterson, L.; Doyle, M.; Monsma, D. The Future of Groundwater: A Report from the 2017 Aspen Nicholas Water Forum; The Aspen Institute: Washington, DC, USA, 2017. Available online: https://nicholasinstitute.duke. edu/publications / future-groundwater (accessed on 22 December 2017).

10. DeSimone, L.A.; McMahon, P.B.; Rosen, M.R. The Quality of Our Nation's Waters: Water Quality in the Principal Aquifers of the United States, 1991-2010; U.S. Geological Survey: Reston, VA, USA, 2015. Available online: https:/ / pubs.usgs.gov/ circ/1360/pdf/circ1360report.pdf (accessed on 4 October 2017).

11. Konikow, L.F. Groundwater Depletion in the United States (1900-2008); USGS Scientific Investigations Report 2013-5079; U.S. Geological Survey: Reston, VA, USA, 2013. Available online: https:/ / pubs.usgs.gov/sir/ 2013/5079/ (accessed on 9 May 2018).

12. Reilly, T.E.; Dennehy, K.F.; Alley, W.M.; Cunningham, W.L. Ground-Water Availability in the United States; USGS Circular 1323; U.S. Geological Survey: Reston, VA, USA, 2008.

13. Mukherji, A.; Shah, T. Groundwater socio-ecology and governance: A review of institutions and policies in selected countries. Hydrogeol. J. 2005, 13, 328-345. [CrossRef]

14. Theesfeld, I. Institutional challenges for national groundwater governance: Policies and issues. Ground Water 2010, 48, 131-142. [CrossRef] [PubMed]

15. Knüppe, K. The challenges facing sustainable and adaptive groundwater management in South Africa. Water SA 2011, 37, 67-79. [CrossRef]

16. Knüppe, K.; Pahl-Wostl, C. A framework for the analysis of governance structures applying to groundwater resources and the requirements for the sustainable management of associated ecosystem services. Water Resour. Manag. 2011, 25, 3387-3411. [CrossRef]

17. Foster, S.; Garduño, H. Groundwater-resource governance: Are governments and stakeholders responding to the challenge? Hydrogeol. J. 2013, 21, 317-320. [CrossRef]

18. Varady, R.G.; Zuniga-Teran, A.A.; Gerlak, A.K.; Megdal, S.B. Modes and approaches of groundwater governance: A survey of lessons learned from selected cases across the globe. Water 2016, 8, 417. [CrossRef] 
19. Megdal, S.B.; Gerlak, A.K.; Huang, L.Y.; Delano, N.; Varady, R.G.; Petersen-Perlman, J.D. Innovative Approaches to Collaborative Groundwater Governance in the United States: Case Studies from Three High-Growth Regions in the Sun Belt. Environ. Manag. 2017, 59, 718-735. [CrossRef] [PubMed]

20. Albrecht, T.R.; Varady, R.G.; Zuniga-Teran, A.A.; Gerlak, A.K.; Staddon, C. Governing a shared hidden resource: A review of governance mechanisms for transboundary groundwater security. Water Secur. 2017, 43-56. [CrossRef]

21. Food and Agriculture Organization of the United Nations/Global Environment Facility. Groundwater Governance: A Global Framework for Country Action. 2010. Available online: http://www. groundwatergovernance.org/fileadmin/user_upload/gwg/documents/GWG\%20prodoc\%20update\%20.pdf (accessed on 13 December 2017).

22. Organisation for Economic Co-Operation and Development. Water Governance Initiative. 2017. Available online: https://www.oecd.org/cfe/regional-policy/water-governance-initiative.htm (accessed on 20 December 2017).

23. Michaels, S.; Kenney, D.S. State approaches to watershed management: Transferring lessons between the Northeast and Southwest. In Watershed Management and Operations Management 2000, Proceedings of the Watershed Management and Operations Management Conferences 2000, Fort Collins, CO, USA, 20-24 June 2000; ASCE Library: Fort Collins, CO, USA, 2000; pp. 1-10. [CrossRef]

24. Schlager, E.; Blomquist, W. Local Communities, Policy Prescriptions, and Watershed Management in Arizona, California and Colorado. In Proceedings of the Constituting the Commons: Crafting Sustainable Commons in the New Millennium, the Eighth Biennial Conference of the International Association for the Study of Common Property, Bloomington, IN, USA, 31 May-4 June 2000.

25. Wagner, M.; Kaiser, R.; Kreuter, U.; Wilkins, N. Managing the commons Texas style: Wildlife management and ground-water associations on private lands. J. Am. Water Resour. Assoc. 2007, 43, 698-711. [CrossRef]

26. Sophocleous, M. Review: Groundwater management practices, challenges, and innovations in the High Plains aquifer, USA-lessons and recommended actions. Hydrogeol. J. 2010, 18, 559-575. [CrossRef]

27. Welsh, L.W.; Endter-Wada, J. Policy debates over the Southern Nevada Water Authority Groundwater Development Project: Beneficial uses of water in a desert. J. Southwest 2017, 59, 302-337. [CrossRef]

28. Blomquist, W. Dividing the Waters: Governing Groundwater in Southern California; ICS Press Institute for Contemporary Studies: San Francisco, CA, USA, 1992; 413p.

29. Schlager, E. Challenges of governing groundwater in U.S. western states. Hydrogeol. J. 2006, 14, 350-360. [CrossRef]

30. Norman, E.S.; Bakker, K. Transgressing scales: Water governance across the Canada-US borderland. Ann. Assoc. Am. Geogr. 2009, 99, 99-117. [CrossRef]

31. Cosens, B.; Williams, M. Resilience and water governance: Adaptive governance in the Columbia River basin. Ecol. Soc. 2012, 17, 3. [CrossRef]

32. Sugg, Z.P.; Varady, R.G.; Gerlak, A.K.; de Grenade, R. Transboundary groundwater governance in the Guarani Aquifer System: Reflections from a survey of global and regional experts. Water Int. 2015, 40, 377-400. [CrossRef]

33. Blomquist, W.; Heikkila, T.; Schlager, E. Institutions and conjunctive water management among three western states. Nat. Resour. J. 2001, 41, 653-683.

34. Heikkila, T. Institutional boundaries and common-pool resource management: A comparative of water management programs in California. J. Policy Anal. Manag. 2004, 23, 97-117. [CrossRef]

35. Sugg, Z.P.; Ziaja, S.; Schlager, E.C. Conjunctive groundwater management to socio-ecological disturbances: A comparison of 4 western U.S. States. Texas Water J. 2016, 7, 1-24.

36. Kiparsky, M.; Milman, A.; Owen, D.; Fisher, A.T. The importance of institutional design for distributed local-level governance of groundwater: The case of California's Sustainable Groundwater Management Act. Water 2017, 9, 755. [CrossRef]

37. United Nations Development Group. Indicators for Monitoring the Millennium Development Goals; United Nations: New York, NY, USA, 2003; 106p.

38. Wade, R. The management of common-property resources: Collective action as an alternative to privitisation or state regulation. Cambr. J. Econ. 1987, 11, 95-106. [CrossRef]

39. Ostrom, E.; Burger, J.; Field, C.B.; Norgaard, R.B.; Policansky, D. Revisiting the Commons: Local lessons, global challenges. Science 1999, 284, 278-282. [CrossRef] [PubMed] 
40. Dietz, T.; Ostrom, E.; Stern, P.C. The struggle to govern the commons. Science 2003, 302, 1907-1912. [CrossRef] [PubMed]

41. Marothia, D.K. Institutions for common pool resources. In Institutional Change in Indian Agriculture; Pal, S., Mruthyunjaya, Joshi, P.K., Saxena, R., Eds.; National Centre for Agricultural Economics and Policy Research: New Delhi, India, 2003; pp. 61-80.

42. Anderies, J.M.; Janssen, M.A. Sustaining the Commons, 1st ed.; Center for the Study of Institutional Diversity: Tempe, AZ, USA, 2013.

43. Feeny, D.; Berkes, F.; McCay, B.J.; Acheson, J.M. The tragedy of the commons: Twenty-two years later. Hum. Ecol. 1990, 18, 1-19. [CrossRef] [PubMed]

44. Schlager, E. Community management of groundwater. In The Agricultural Groundwater Revolution: Opportunities and Threats to Development. Vol. 3: Comprehensive Asssesment; Giordano, M., Villhoth, K., Eds.; CABI Publishing: Wallingford, UK, 2007; 419p.

45. Morris, B.L.; Lawrence, A.R.L.; Chilton, P.J.C.; Adams, B.; Calow, R.C.; Klinck, B.A. Groundwater and Its Susceptibility to Degradation: A Global Assessment of the Problem and Options for Management; Early Warning and Assessment Report Series, RS. 03-3; United Nations Environment Programme: Nairobi, Kenya, 2003.

46. Galloway, D.L.; Burbey, T.J. Review: Regional land subsidence accompanying groundwater extraction. Hydrogeol. J. 2011, 19, 1459-1486. [CrossRef]

47. Hou, Z.Y.; Lu, W.X.; Chu, H.B.; Luo, J.N. Selecting parameter-optimized surrogate models in DNAPL contaminated aquifer remediation strategies. Environ. Eng. Sci. 2015, 32, 1016-1026. [CrossRef]

48. Kelly, B.F.; Timms, W.A.; Andersen, M.S.; McCallum, A.M.; Blakers, R.S.; Smith, R.; Rau, G.C.; Badenhop, A.; Ludowici, K.; Acworth, R.I. Aquifer heterogeneity and response time: The challenge for groundwater management. Crop Pasture Sci. 2013, 64, 1141-1154. [CrossRef]

49. Prakash, O.; Datta, B. Characterization of groundwater pollution sources with unknown release time history. J. Water Resour. Prot. 2014, 6, 337-350. [CrossRef]

50. Foster, S.; Hirata, R.; Andreo, B. The aquifer pollution vulnerability concept: Aid or impediment in promoting groundwater protection? Hydrogeol. J. 2013, 21, 1389-1392. [CrossRef]

51. Sanchez, R.; Lopez, V.; Eckstein, G. Identifying and characterizing transboundary aquifers along the Mexico-US border: An initial assessment. J. Hydrol. 2016, 535, 101-119. [CrossRef]

52. Garrick, D.; Lane-Miller, C.; McCoy, A.L. Institutional innovations to govern environmental water in the Western United States: Lessons for Australia's Murray-Darling Basin. Econ. Pap. 2011, 30, 167-184. [CrossRef]

53. Council of Canadian Academies. The sustainable management of groundwater in Canada. In Expert Panel on Groundwater, Report to the Government of Canada; Council of Canadian Academies: Ottawa, ON, Canada, 2009.

54. Gleeson, T.; Alley, W.M.; Allen, D.M.; Sophocleous, M.A.; Zhou, Y.; Taniguchi, M.; VanderSteen, J. Towards sustainable groundwater use: Setting long-term goals, backcasting, and managing adaptively. Groundwater 2012, 50, 19-26. [CrossRef] [PubMed]

55. McMahon, P.B.; Plummer, L.N.; Böhlke, J.K.; Shapiro, S.D.; Hinkle, S.R. A comparison of recharge rates in aquifers of the United States based on groundwater-age data. Hydrogeol. J. 2011, 19, 779. [CrossRef]

56. Grafton, R.Q.; Libecap, G.; McGlennon, S.; Landry, C.; O’Brien, B. An integrated assessment of water markets: A cross-country comparison. Rev. Environ. Econ. Policy 2011, 5, 219-239. [CrossRef]

57. Abrams, R.H. Legal convergence of East and West in contemporary American water law. Environ. Law 2012, 42, 65-92.

58. Weinert, N. Solutions for interstate groundwater allocation and the implications of Day. Texas Environ. Law J. 2014, 44, 105-144.

59. Ross, A. Groundwater governance in Australia, the European Union and the Western USA. In Integrated Groundwater Management; Jakeman, A.J., Barreteau, O., Hunt, R.J., Rinaudo, J.D., Ross, A., Eds.; Springer: Cham, Switzerland, 2016; pp. 145-171.

60. Koontz, T.M.; Newig, J. From planning to implementation: Top-down and bottom-up approaches for collaborative watershed management. Policy Stud. J. 2014, 42, 416-442. [CrossRef]

61. Wegner, D. Adaptive Management and Water: The Importance of Science to Public Policy and Water Management. 2017. Available online: https://wrrc.arizona.edu/sites/wrrc.arizona.edu/files/WRRC_2017.pdf (accessed on 26 October 2017). 
62. US Army Corps of Engineers. Addressing Climate Change in Long-Term Water Resources Planning and Management: User Needs for Improving Tools and Information; US Army Corps of Engineers: Washington, DC, USA, 2011. Available online: https://www.usbr.gov/climate/userneeds/docs/LTdoc.pdf (accessed on 7 February 2018).

63. Dworsky, L.B.; Allee, D.J.; North, R.M. Water resources planning and management in the United States federal system: Long term assessment and intergovernmental issues. Nat. Resour. J. 1991, 31, 475-547.

64. Blomquist, W.; Heikkila, T.; Schlager, E. Building the agenda for institutional research in water resource management. J. Am. Water Resour. Assoc. 2004, 40, 925-936. [CrossRef]

65. Gerlak, A.K.; Megdal, S.B.; Varady, R.G.; Richards, H. Groundwater Governance in the U.S.: Summary of Initial Survey Results. 2013. Available online: https:/ / wrrc.arizona.edu/sites/wrrc.arizona.edu/files/pdfs/ GroundwaterGovernanceReport-FINALMay2013.pdf (accessed on 20 December 2017).

66. Hutson, S.S.; Barber, N.L.; Kenny, J.F.; Lindsey, K.S.; Lumia, D.S.; Maupin, M.A. Estimated Use of Water in the United States in 2000; U.S. Geological Survey: Reston, VA, USA, 2004. Available online: https:/ / pubs.usgs.gov/circ/2004/circ1268/pdf/circular1268.pdf (accessed on 9 May 2018).

67. Foster, S.; Chilton, J.; Nijsten, G.J.; Richts, A. Groundwater-A global focus on the 'local resource'. Curr. Opin. Environ. Sustain. 2013, 5, 685-695. [CrossRef]

68. Western Governors' Association. Western Governors' Association Policy Resolution 2015-08: Water Resource Management in the West; Western Governors' Association: Denver, CO, USA, 2018. Available online: http:/ / westgov.org/images/editor/RESO_Water_Resources_Final_Version_08.pdf (accessed on 8 May 2018).

(C) 2018 by the authors. Licensee MDPI, Basel, Switzerland. This article is an open access article distributed under the terms and conditions of the Creative Commons Attribution (CC BY) license (http:/ / creativecommons.org/licenses/by/4.0/). 